Cahiers du MONDE RUSSE

\section{Cahiers du monde russe}

Russie - Empire russe - Union soviétique et États indépendants

40/1-2 | 1999

Archives et nouvelles sources de l'histoire soviétique, une réévaluation

\title{
Letter-writing and the State
}

Reader correspondence with newspapers as a source for early Soviet history

Matthew E. Lenoe

\section{(2) OpenEdition}

\section{Journals}

Electronic version

URL: http://journals.openedition.org/monderusse/8

DOI: $10.4000 /$ monderusse. 8

ISSN: $1777-5388$

Publisher

Éditions de l'EHESS

\section{Printed version}

Date of publication: 1 January 1999

Number of pages: 139-170

ISBN: 2-7132-1314-2

ISSN: $1252-6576$

Electronic reference

Matthew E. Lenoe, « Letter-writing and the State », Cahiers du monde russe [Online], 40/1-2 | 1999,

Online since 15 January 2007, Connection on 03 May 2019. URL : http://journals.openedition.org/ monderusse/8 ; DOI : 10.4000/monderusse.8 


\section{LETTER-WRITING AND THE STATE}

\section{Reader correspondence with newspapers as a source for early Soviet history}

As RUSSIAN ARCHIVES HAVE EXTENDED ACCESS to their files over the last decade historians have come upon hundreds of thousands of reader letters to newspapers, dating back to the earliest years of Soviet history. The best-known collection is the archive of the Central Committee's Krest'ianskaia gazeta, held in the Russian State Archive of the Economy. But Moscow archives also contain large collections of letters to Rabochaia gazeta, Rabotnitsa, and Gudok (organ of the railroad workers' labor union). Intelligence reports on popular mood (svodki) prepared for upperlevel Party officials based on letters to newspapers are also scattered throughout Russian archives. Svodki in the files of the Central Committee and the Moscow oblast' (province) Party Committee, for example, include material from letters to Pravda, Batrak, Uchitel'skaia gazeta (organ of the teachers' union), Golos tekstilei (organ of the textile workers' union), and Rabochaia Moskva . ${ }^{1}$

\footnotetext{
1. The Krest'ianskaia gazeta letter archive is located in the Rossiiskii Gosudarstvennyi Arkhiv Ekonomiki (RGAE), fond 396, the Rabochaia gazeta and Rabotnitsa archive in Rossiiskii Tsentr Khraneniia i Izucheniia Dokumentov Noveishei Istorii (RTsKhIDNI), fond 610, and the Gudok archive in Gosudarstvennyi Arkhiv Rossiiskoi Federatsii (GARF), fond 9613. For examples of intelligence reports on popular mood containing excerpts from letters to Batrak, see RTsKhIDNI, f. 17, op. 85, d. 21, 11. 126-179. For svodki excerpting Uchitel'skaia gazeta, see ibid., 11. 86-121; for svodki from Rabochaia Moskva and Uchitel'skaia gazeta, see Tsentral'nyi Gosudarstvennyi Arkhiv Obshchestvennykh Dvizhenii g. Moskvy (TsGAOD g. Moskvy), f. 3, op. 9, d. 81, 11. 103-128; for svodki based on letters to Golos tekstilei, see ibid., 11. 166-67. Two collections of letters published within the last year are A. K. Sokolov, ed., Golos naroda. Pis'ma i otkliki riadovykh sovetskikh grazhdan o sobytiiakh 1918-1932 gg. (Moscow: Rosspen, 1998) and A. Ia. Livshin, I. B. Orlov, eds, Pis'ma vo vlast', 1917-1927: zaiavleniia, zhaloby, donosy, pis'ma $v$ gosudarstvennye struktury i bol'shevistskim vozhdiam (Moscow: Rosspen, 1998).
} 
Like any source, the letters cannot be used effectively without an understanding of who produced them, what their purposes were, and what conventions governed their composition. Letter-writing to Soviet newspapers was a practice with multiple social, political, and even economic functions. For their authors the letters were a channel for petitions to power of all sorts, whether for restoration of rations, a trip to Moscow, or redress of injustice. Writing letters to the papers was also a means of proving oneself as a civic-minded activist, a morally serious person worthy of admission to the Party. Would-be journalists wrote letters to the newspapers in hopes of being hired on regular staff. Some authors wrote in order to express opinions or protest the Party's political line. Others sought to settle private quarrels with political or criminal denunciations.

Yet whatever the motives behind them, letters to Soviet newspapers (and to other Soviet authorities, for that matter) do not represent, except in very distorted form, their authors' private aspirations, opinions, or beliefs. Bolshevik Party leaders and officials constructed the practice of letter-writing, soliciting letters from their subjects, setting the agenda for their correspondence, coaching them on acceptable ways to address power, and deciding which of their missives would be published. For Party authorities the solicitation of letters was a tool of power. They needed letters to gauge popular mood, monitor the state apparatus, educate the uncultured masses, and facilitate the centralized distribution of goods, power, and privileges. The ordinary Soviet subject corresponded with the newspapers inside a frame already built by Party officials and journalists. Letters to the newspaper were artifacts of the interaction between rulers and ruled. Although it is possible to find in these letters indirect evidence about private political opinions, resistance to Stalinism, and individual manipulation of the Soviet state, they have much greater value as direct windows on the everyday functioning of Soviet society, the instruments of power, and the ways in which agents of the Soviet state acted to shape the public identity of their subjects.

In prerevolutionary Russia both the government and its opponents had solicited reader letters to their press organs as part of their efforts at political education and organization. The Tsarist state had begun using reader letters as a tool of political education as early as 1881, when the Ministry of Internal Affairs began publishing Sel'skii vestnik. This was a weekly paper for peasants which ran a regular section of reader letters. The overall purpose of the newspaper was to counteract revolutionary propaganda in the countryside following the assassination of Alexander II. In particular Ministry officials wanted to scotch rumors that the government would soon divide all large landholdings up among the peasants in a "final repartition."

According to James Krukones, the editors hoped that printing reader letters would advance the paper's didactic mission. They instructed readers on desirable topics for their letters, including how to raise agricultural productivity, learn a

2. James H. Krukones, To the people: The Russian government and the newspaper Sel'skii vestnik 1881-1917(New York: Garland, 1987): 8-18. 
trade, and stay sober. They also requested information on prices and local real estate markets. As with Soviet newspapers in later years, they strove to set an agenda for their correspondents. The agenda was also enforceable, for the paper would only publish on topics the editors deemed appropriate. Letters actually printed tended toward self-improvement tips and complaints about peasant vice, alcoholism, and general "backwardness."

Beginning at the turn of the century Social Democratic newspapers, among them Iskra and later Pravda, published letters from worker and peasant activists. Lenin advocated soliciting letters from ordinary manual laborers in order to collect information about revolutionary activity all around the country, and to maintain contact with rank-and-file revolutionaries. The practice, however, had another function, that of political education. Workers and peasants who wrote to the newspaper would raise their own political consciousness and their general level of culture in preparation for leading an insurgent proletariat. Correspondence with the newspaper, like face-to-face political study circles, was expected to be a school for revolutionaries.

The early Social Democratic press shared with Sel'skii vestnik the goal of "raising the cultural level of the masses," making them more disciplined, productive members of society. Writers to both the government and revolutionary press addressed a tutelary authority, ostensibly the bearer of higher culture and political consciousness. In both cases newspaper editors saw letter-writing as a tool of education and political persuasion. ${ }^{3}$

After the Bolsheviks seized power in 1917, their new official press continued to solicit reader letters. During the Civil War Soviet newspapers, in particular Pravda and Bednota, the Central Committee's publication for peasants, encouraged readers from "the laboring classes" to write in with denunciations of shirkers and reports on the progress of the war effort. Bednota generally published those letters which modeled conscientious participation in the war effort or denounced malefactors, incompetents, and slackers. On March 18, 1919, for example, the paper ran a letter describing how mechanics and engineers at a railroad repair shop donated a day of work to repair 47 train cars for military use. The piece was headlined, "If everyone just did it like this!" Published letters demonstrating enthusiasm generally fit with some ongoing propaganda campaign, and they were often solicited. The railroad repair story, for example, was part of a campaign to encourage workers to donate time to repair the Bolsheviks' locomotive park. On the same page Bednota published an exhortation to readers to volunteer for transport repair work. "Comrades!" this began, "Do not allow the enemy victory over the hungry workers. Go to work on transport, because the fate of the country depends on transport!"4

Alongside such motivational pieces, Bednota also printed letters that denounced corrupt officials and described their punishment. The purpose appears to have been both to bolster morale by showing Soviet power exposing class enemies, and to

3. Ibid.: 138-147.

4. Bednota (March 18, 1919). 
deter would-be slackers, deserters, and saboteurs. On March 18, 1919, in the same issue as the story about the railway mechanics' volunteer work, the paper published brief descriptions of corrupt Communists who had been exposed and prosecuted. The headlines "On the black board (of shame)" ran above stories about a village soviet chair who had engaged in "kulak speculation," a commissar who had broken his Lenten fast with bread made from requisitioned flour, and a former tsarist secret police officer who had infiltrated the Cheka in Rzhevsk. ${ }^{5}$

Bednota's editors did not simply ask readers to write, they solicited and published letters which reinforced current propaganda campaigns. They acted to structure the flow of information coming into their offices. At a time when Moscow newspapers had few or no paid correspondents in the provinces, the editors had to ensure that Bednota received material that fit into ongoing propaganda campaigns. Unpaid letter-writers were a vital source of copy for the paper, serving as an unofficial information network. It is particularly interesting, then, to find hints that a high proportion of Bednota's subscribers and letter-writers were local officials, such as village soviet chairmen, or rural "intellectuals," such as village schoolteachers. The paper's audience, and its unpaid correspondents, probably did not really represent "the people," or "the laboring masses," but rather local officialdom. This pattern, in which local officials and Party activists provided the newspaper with the kind of letters it needed, would be repeated throughout the 1920 s and into the 1930s. ${ }^{6}$

Soon after taking power the Bolsheviks began to elaborate the uses of reader letters, gleaning from them information on popular moods and abuses by local officials. Soviet leaders, for example, began consulting these letters for information on the mood of particular segments of the population. Lenin set the precedent for this practice, asking Pravda and Bednota to forward letters to him on a regular basis

\section{Ibid.}

6. Steven Coe in his Peasants, the state, and the languages of NEP: The rural correspondents' movement in the Soviet Union, 1924-1928 (Ph.D. diss., University of Michigan, 1993): 76-80, suggests that before 1924 Bednota's correspondents were primarily "party members, village officials, members of the 'village intelligentsia' and occasionally demobilized or on-leave Red Army soldiers." As evidence Coe cites efforts to recruit correspondents by Bednota editors at a meeting of delegates of peasant Committees of the Poor (1918) and the Second All-Russian Conference of Workers in the Countryside (1920). He also discusses efforts in 1921 by Pravda and Izvestiia to get local Party organizations to appoint regular correspondents from among their ranks. During the Civil War and after the Central Committee provided subscriptions to Bednota free to most important rural institutions, including reading huts, township (volost') executive comittees, local offices of the Commissariat of Agriculture, and local political education departments (Glavpolitprosvet) (RTsKhIDNI, f. 17, op. 112, d. 323, 1. 9). A Central Committee report from 1922 or 1923 (admittedly after a drastic drop in circulation from $600,000$ to $50,000-100,000)$ described Bednota as the newspaper of rural officialdom (RTsKhIDNI, f. 17, op. 60, d. 870, 11. 92-99). The same report noted that in the Ukraine at least rural newspapers were delivered to local government offices and were not read by ordinary peasants (ibid.: 1-4).

The same pattern of distribution and letter-writing applied to the prerevolutionary state newspaper for peasants, Sel'skii vestnik. From its founding in 1881 until 1890 over one-half of Sel'skii vestnik's subscribers were township offices which received the paper for free. In 1882, $35 \%$ of all letters published in Sel'skii vestnik were identifiable as being from local officials, priests, or schoolteachers. In 1890, 40\% were (J.H. Krukones, op. cit.: 253, 260-61). 
during the Civil War. ${ }^{7}$ Using letters to the newspaper as a gauge of popular mood, however, was not merely an idiosyncracy of the Bolshevik leader. It was part of a much wider-ranging effort to set up intelligence channels for monitoring the political opinions of different social groups. Recent works by Vladlen Izmozik and Peter Holquist indicate that while surveillance of the political moods of the populace had precedents in earlier Russian statecraft and the practices of the combatant powers in World War I, the Bolsheviks set about the task with particular intensity. Within days of the October Revolution the Petrograd Party Committee sent out questionnaires to ward authorities on the attitudes of Petrograd residents to the Bolshevik seizure of power. Throughout 1918 Party and Soviet authorities, including the Cheka, provincial Party committees, the All-Russian Central Executive Committee, and the Russian Telegraph Agency, strove to set up intelligence networks which would inform them of the public mood. In addition to reader letters to the newspaper, the sources of information were perlustrated private letters and reports from Party agitators, Russian Telegraph Agency correspondents, and Cheka informers. By 1919 the preparation of svodki, intelligence summaries based on these materials, was well-established in a variety of Soviet institutional settings. Journalism was just one of these. ${ }^{8}$

Also during the Civil War years Soviet authorities began considering the use of reader letters as a check on corrupt local officials. Such letters would become known in Bolshevik parlance as "signals from the localities." This function was implicit in Bednota's letters reporting the prosecution of corrupt local officials, and it was endorsed by Lenin (in his article "On the character of our newspapers") in November 1918 and the VIII Party Congress in March 1919. However, serious efforts to institutionalize the use of reader letters to monitor local bureaucracies did not begin until well into the era of the New Economic Policy. ${ }^{9}$

By the end of the Civil War, then, the practice of soliciting reader letters had emerged as a central part of Soviet newspaper work. The uses of reader letters by the state apparatus which developed during this period would continue throughout the 1920s and 1930s. From the point of view of state authorities reader letters were

7. For reference to Lenin's requests for such letters from Bednota, see B. S. Burkov, B. A. Miakushkov, Vse bylo tak... (Moscow: Mysl', 1991): 11. On Lenin's instructions to the Pravda editorial board to organize a corps of regular "worker correspondents," see The great Soviet encyclopedia (Moscow: Sovetskaia entsiklopediia, 1974), s.v. "Worker and village correspondents' movement."

8. Vladlen Izmozik, Glaza i ushi rezhima. Gosudarstvennyi politicheskii kontrol' za naseleniem Sovetskoi Rossii v 1918-1928 gg. (SPb: Izdatel'stvo S. Peterburgskogo universiteta, 1995): 3-43. See also Peter Holquist, "Information is the alpha and omega of our work: Bolshevik surveillance in its pan-European context," Journal of Modern History, 69, 3 (Sept. 1997): 415-450.

9. For the VIII Party Congress' resolution calling for a press which would expose "the crimes of various types of persons in high posts and institutions, showing the mistakes and shortcomings of Soviet and Party organizations," see $O$ partiinoi i sovetskoi pechati: sbornik dokumentov (Moscow: Izdatel'stvo "Pravda," 1954): 212. On Lenin's November 1918 letter, see Peter Kenez, The birth of the propaganda state: Soviet methods of mass mobilization, 19171929 (Cambridge: Cambridge University Press, 1985): 49. 
instruments of political education, cultural enlightenment, surveillance of local government officials, and intelligence collection. Letter-writing to the newspapers was an important mechanism in the functioning of official Soviet society. ${ }^{10}$

\section{Instruction of worker/peasant correspondents}

In the years 1923-1924 high circulation Soviet newspapers were organizing a regular body of "worker and village correspondents." These were supposed to be ordinary working people who would write into the newspapers regularly. Officials in the Party's agitprop apparatus hoped that the correspondents would expose corrupt local officials, provide information on popular moods, and help to mobilize opinion behind the Bolshevik regime. They also hoped to use the worker and village correspondents movement as a tool to educate a new worker/peasant intelligentsia. In pursuit of all of these goals Soviet newspaper editors and journalists during the $1920 \mathrm{~s}$ and 1930s instructed their worker and village correspondents on appropriate themes and language for their letters. A striking example of readers' response is in the letter archive of Rabochaia gazeta at RTsKhIDNI, the central archive of the Communist Party. The archive contains a large file of letters on "articles and shorts (zametki) by Rabochaia gazeta correspondents on the question of repairing and putting into operation industrial enterprises" from the summer and fall of 1924. Postwar reconstruction of industry was a major theme of Party propaganda at this time, playing out in forums from Rabochaia gazeta to Fedor Gladkov's novel Cement. Rabochaia gazeta requested information about the reopening of provincial factories from its correspondents, who responded with zeal. The file contains hundreds of letters. Typical headlines are "Another factory opened," "Another victory," "Smoke rolls again from the chimneys of three factories," and "Another victory on the labor front."11

A high proportion of letter authors in this file were low level Party officials, trade union activists, or representatives of factory management. The "worker correspondent" Rodin, for example, was also a member of an uezd (county) Party Committee. Other worker correspondents belonged to trade union factory committees, guberniia (province) trade union Departments of Labor, or cooperative administration. Some of the letters were typed, indicating that the author probably had access to a typewriter at a government office. ${ }^{12}$

10. By "official Soviet society" I mean the combined body of the Party, the Komsomol, the trade unions, activist organizations such as the civil defense corps OSOAVIAKHIM, and the state apparatus. Soviet commentators referred to this combined body as obshchestvennost', a term which before the October Revolution had meant something like "civil society" or "public opinion."

11. RTsKhIDNI, f. 610, op. 1, d. 8, 11. 1-10, 15, 19-20. For documentation on Rabochaia gazeta's instruction of its worker correspondents see RTsKhIDNI, f. 17, op. 60, d. 935, 11. 2629. Instruction was to be provided through two "roving instructors" who would visit local worker correspondent "circles," as well as through individual letters and a special journal.

12. RTsKhIDNI, f. 17, op. 60, d. 935, 11. 1-27, 71. 
Newspapers used a number of channels to instruct worker and village correspondents in the 1920s. The lessons themselves were haphazard and of uneven quality, but instructional materials were distributed widely. According to a Central Committee Press Department survey done in late 1923, Soviet trade union and "mass worker" newspapers used articles, conferences, individual letters, circulars, and roving instructors to inform worker and village correspondents what and how to write. In addition, newspapers published regular instructional journals for the correspondents. ${ }^{13}$

Although Pravda editor Nikolai Bukharin and editorial staff secretary M. I. Ul'ianova (Lenin's sister) advocated a semi-autonomous worker and village correspondents movement for a brief period in the years 1924-1925, after 1926 official guidelines called for direct supervision of the correspondents by Communists on local newspaper staffs. ${ }^{14}$ In actual practice, too, the trend in the later 1920 s and early 1930 s seems to have been towards greater supervision and instruction of correspondents. A new genre of Soviet newspaper work, "mass journalism," was predicated on close guidance and coordination of correspondents' efforts by professional journalists. The goal was to channel the correspondents' energies toward the Party's agitprop priorities. ${ }^{15}$

Newspaper efforts to supervise correspondents continued into the 1930s. In April 1931, for example, the Central Committee's Orgbiuro passed a resolution calling for involvement of worker and village correspondents in the new propaganda campaign for "mastering technology." Among the measures the Orgbiuro ordered were the establishment of special "Press Sections" attached to raion (county) Party Committees, the organization of courses to prepare worker and village correspondents by local newspapers and Party Committees, and the publication by Pravda of a special supplement for correspondents twice a month. ${ }^{16}$ To cite one example of response to the Orgbiuro resolution, the central newspaper Izvestiia moved to set up instruction of worker correspondents by its provincial news bureaus, link its Department of Organizational-Mass Work with several factories, call regular meetings of worker and village correspondents, use the newspaper's journalists on assignment outside Moscow to train the correspondents, and publish a regular section which would review correspondents' contributions to workplace publications. ${ }^{17}$ As

13. Ibid., 11. 1-102. Two of the instructional journals were Pravda's Raboche-krest'ianskii korrespondent and Rabochaia Moskva's Put' rabsel'kora.

14. On the shift toward direct Party supervision of the worker/peasant correspondents' movement in 1926, see Julie Kay Mueller, A new kind of newspaper: The origins and development of a Soviet institution, 1921-1928 (Ph.D. diss., University of California/Berkeley, 1992): 264-315.

15. On "mass journalism" (the organization of news events such as socialist competitions and "production reviews") as a tool for organizing worker/peasant correspondents, see Matthew Lenoe, Stalinist mass journalism and the transformation of Soviet newspapers, 1926-1932 (Ph.D. diss., University of Chicago, 1997), chapter 5.

16. RTsKhIDNI, f. 17, op. 114, d. 228, 11. 61-65.

17. TsGAOD g. Moskvy, f. 420, op. 1, d. 59, 11. 120-131. 
of the summer of 1931 Gudok, the organ of the railwaymen's labor union, was sending out "organizers" and "instructors" to lecture worker correspondents on appropriate themes for their letters. ${ }^{18}$ In 1933 the paper was instructing worker correspondents by means of individual letters of instruction, regular conferences, and its journal Rabkor zheleznodorozhnik. ${ }^{19}$

The purpose of the above examples is not to suggest either that all letter-writers were regular worker/village correspondents or that all followed the agendas which Party authorities attempted to set. In fact, the records of Gudok cited above make a distinction between the paper's total of 40,000 worker correspondents" and its aktiv (meaning roughly "the corps of activists") of 1,500. The head of Komsomol'skaia pravda's letters department made the same distinction at a conference in January 1935. Members of the aktiv were in regular touch with the editors, while anyone who had ever sent in a letter qualified as a rank-and-file worker correspondent. The activists received more intensive and direct supervision than the one-time authors. However, both groups were influenced by the editors' instructions, whether transmitted on the pages of the newspaper itself, in trade journals, at meetings, or in individual letters. ${ }^{20}$

The practice of letter-writing as a whole was not spontaneously motivated "from below." Nor did letter-writers choose the topics for their letters in a vacuum. They were often prompted "from above" so that their letters reflected the Party's own agenda. The orderly filing of letters by topic in the Krest'ianskaia gazeta archive at the Russian State Archive of the Economy is evidence of this. Many of the topic headings match the newspaper's own thematic organization: "The alliance of countryside and city," "Cooperatives," "The countryside - old and new," "Taxes," "Agriculture and agronomy," "Enlightenment," "The Red Army," "Our newspaper," "Wrecking and malfeasance on collective farms," "On the opposition." 21 The ability of Krest'ianskaia gazeta's office staff to file letters this way indicates that a high proportion of letter-writers followed the agenda set by the newspaper. When a newspaper reader wrote a letter to the editor, s/he was participating in a practice structured by agents of the Soviet state for state purposes.

18. GARF, f. 9613 , op. 2, d. 82, 11. 1-5.

19. Ibid., d. 94, 11. 1-2ob.

20. Ibid. A report on Gudok's work by a "brigade" of Komsomol "raiders" from 1933 noted that individual letters of instruction were sent out only to the aktiv. Other letter-writers, the report claimed, were reached through members of the aktiv who were supposed to run instructional meetings, as well as through Rabkor zheleznodorozhnik and conferences organized by the editors themselves. The report also noted that worker correspondents were supposed to receive one ruble for each letter published, and that reporters edited letters heavily before publication. Sometimes they even put their own byline on them, so that they received the "honorarium" instead of the worker correspondent. For comments on Komsomol'skaia pravda's work with letters and correspondents, see "Stenogramma soveshchaniia zav. massovym otdelom i otdelom rabochikh pisem tsentral'nykh gazet v Bol'shevistskoi pechati," Jan. 2, 1935, in the library of Komsomol'skaia pravda, Moscow, file "V. Man'kova," TMs.

21. RGAE, f. 396, op. 1-10. 
Party leaders pushed newspapers and local Party organizations to instruct correspondents in part because they saw the movement as a tool for the education of a new "Soviet intelligentsia" of workers and peasants. As a number of scholars have noted, the worker and village correspondents movement served as a kind of "university" where young activists from the "laboring masses" learned to speak the official language of the Soviet state. Both the organizers of the correspondents movement and the participants were aware of this function. Newspapers instructed correspondents in the use of the new Bolshevik vocabulary, while would-be Party members and activists imitated official discourse in their letters and expressed their desire to learn it thoroughly. Like Sel'skii vestnik and the prerevolutionary socialist press, the Soviet newspapers solicited letters in part to educate their audience, especially in correct political thinking. But writing letters to Soviet papers offered the authors a greater potential reward, for the worker and village correspondents movement was organized in part as a channel for upward mobility into the state apparatus. Those letter-writers who strove to learn official language with the ultimate goal of entering the privileged circle of obshchestvennost' both participated in and reinforced a state-structured discourse. Their letters did not so much express private identity or mentalité, as a willingness to speak Bolshevik language in exchange for the benefits distributed by the Soviet state. ${ }^{22}$

A 1925 letter to Krest'ianskaia gazeta from a 22-year old Ukrainian peasant, Ivan Sergeevich Eroshchenko, exemplifies the readiness of would-be activists to adopt Bolshevik language and ideological categories in order to gain a share of the benefits offered by the state. Eroshchenko opened his letter, which he titled, "My last call," with a request for unspecified aid from the newspaper editors. He continued with an account of the difficulties he had encountered in trying to remake himself as a village correspondent and activist in his village.

"When I began to arm myself with Krest'ianskaia gazeta, I took the newspaper's printed page, and got knowledge for myself, and I understood what knowledge is, and [that] knowledge is necessary for our young-newly-blooming life. Because our essential task of youth is to construct political life in the countryside." 23

Eroshchenko then noted that he had received Krest'ianskaia gazeta's instructional materials on organizing a "circle" of village correspondents, and thanked the editors for them. Unfortunately, he was encountering difficulties in organizing villagers to subscribe to the newspaper.

22. On the worker and village correspondents movement as a tool for educating workers and peasants in Bolshevik language, see Jeffrey Brooks, "Public and private values in the Soviet press, 1921-1928," Slavic Review, 48, 1 (Spring 1989): 18-35; Michael Gorham, "Tongue-tied writers: The Rabsel'kor movement and the voice of the 'new intelligentsiia' in early Soviet Russia," The Russian Review, 55 (July 1996): 412-429; M. Lenoe, Stalinist mass journalism, op. cit.: $34-44$.

23. RGAE, f. 396, op. 3, d. 41, 11. 49-52. 
"Recently I approached the peasantry with these questions, but it is difficult, comrades! to organize out of the peasantry an avant-garde body of activists (peredovoi aktiv). Because the unconscious mass of peasants. So while I was reading them a lecture from the newspaper it discussed the question of constructing a Soviet state, as they say, all was in order, and then, comrades! when matters came to subscribing, to paying a subscription to Krest'ianskaia gazeta, they became not understanding right away, and no longer activists. [...] Well what can you do, they don't have consciousness [...] the peasants are dark, the peasants are illiterate [...] infected with the prayers of the priests, the capitalists, religion." 24

Eroshchenko continued his plaint about peasant ignorance, and then explained that, "I have come to love intensely Soviet worker-peasant power.[...] I want to achieve great knowledge for my life, to guide the state where the government of workers and peasants is." After this sentence he drew a hammer and sickle. He concluded with a request for directions to the newspaper's editorial offices in Moscow, which he wanted to visit.

\footnotetext{
"When you send me a letter, do not forget me, that is, do not refuse my request to send me a map of Moscow and the editorial offices of Krest'ianskaia gazeta; and advice, what documents I should bring with me, or what I should get on the spot. This is because I Eroshchenko want to visit you at the editorial offices in Moscow [...]. Dear Comrades! Don't leave your friend Eroshchenko in the depths in the countryside! And I want to go to stay with you at the editorial offices so that you can arm me with knowledge. and then back again for the struggle with darkness and ignorance! [...]

I will be a world hero of the proletarian revolution! Yes! All hail the alliance of peasants and workers" [here Eroshchenko drew another hammer and sickle - M. L.]. ${ }^{25}$
}

\begin{abstract}
Although more pathetic than most, Eroshchenko's letter epitomizes the striving of would-be Party members and activists to learn Bolshevik categories (political consciousness, peasant ignorance, the alliance of workers and peasants) in order to gain benefits available from the Soviet state. In Eroshchenko's case, these were education and a trip to Moscow. Letter-writers did not need to be beaten on the head with instruction - they actively sought it out. In order to achieve their goal, whether it was becoming a Communist, getting an education and a better job, or making trouble for a neighbor, the authors understood that they had to speak in language Bolshevik officials would understand. The Party's near-monopoly control over the distribution of educational opportunities, jobs, and goods made it necessary for correspondents to learn its language.
\end{abstract}

\title{
24. Ibid.
}




\section{Who wrote the letters?}

A variety of evidence, both anecdotal and statistical, indicates that a high proportion of letter-writers belonged to official Soviet society. These were Party and Komsomol activists, members of local soviets, trade union officials, and other authorities. A very rough estimate for the 1920s would be that one-third of writers to the "peasant press" belonged to officialdom, as did about two-thirds for "leading" Party and Komsomol organs like Pravda and Komsomol'skaia pravda. According to the editors of Krest'ianskaia gazeta, as of January 1926 "almost all" of ten new village correspondents were members of their village soviet. Krest'ianskaia gazeta's statisticians calculated in May 1926 that $21 \%$ of their correspondents were teachers, and $42.5 \%$ were former Red Army soldiers, a group with disproportionately high representation in rural government. According to the same report, $7.5 \%$ of the newspaper's village correspondents belonged to the Party and an additional $20 \%$ to the Komsomol. It is worth noting that Krest'ianskaia gazeta statistics on peasant correspondents during this period appear to have included all letter-writers, not just "activists" who wrote regularly. ${ }^{26}$

In July of 1923 Gudok, one of the first newspapers actively to organize worker correspondents, reported to the Central Committee Press Department that of 522 correspondents, $158(30.3 \%)$ were labor union officials, and another $184(35.2 \%)$ were office workers of some kind. Only $128(24.5 \%)$ were classified as workers. Of the 271 correspondents whose Party status was known, 111 (41.0\%) belonged to the Party or the Komsomol. These 522 correspondents, however, were probably the activists in regular touch with the editors, as Gudok reported receiving 105 letters a day at this time. It is unlikely that each correspondent was writing a letter every four to five days. ${ }^{27}$

If one can make a correlation between the social profile of a newspaper's readership and that of its letter authors, then most writers to Pravda and Komsomol'skaia pravda were probably Party or Komsomol members. A 1926 survey found that $92 \%$ of Komsomol'skaia pravda's readers belonged to the Komsomol. Similarly, a 1929 survey found that $72 \%$ of Pravda's readers were Party members..$^{28}$ In 1925 the Central Committee worker paper, Rabochaia gazeta, reported that $22.9 \%$ of all readers were Communists, and $13.3 \%$ were Komsomols.

26. See Steven Coe, op. cit:: 258; Zhurnalist, 2 (February 1926): $26 ; 12$ (December 1926): 59. I concluded that Krest'ianskaia gazeta's statistics on village correspondents were based on all letters received, not just those of activists, from an examination of an April 1924 report on letters received (see RTsKhIDNI, f. 17, op. 60, d. 892, 1. 13). It is of course possible that this procedure had changed two years later.

27. RTsKhIDNI, f. 17, op. 60, d. 907, 1. 11.

28. Neither survey was based on a sampling of all readers. Also respondents were selfselecting. In each case the newspaper published a questionnaire which could be cut out and mailed in by the reader. For the Komsomol'skaia pravda survey data, see Tsentr Khraneniia Dokumentov Molodezhnykh Organizatsii (TsKhDMO), f. 1, op. 3, d. 22, 11. 23-25. For the Pravda data, see Gazetnoe khoziaistvo, 2 (February 1930): 14, and "Pervye itogi ankety: chitateli o 'Pravde'," Pravdist, 1 (June 4, 1929). 
Communists and Komsomols thus made up more than one-third of readership for this paper at the time. ${ }^{29}$

Data on "youth correspondents" gathered by provincial Komsomol newspapers in the years 1926-1927 also indicated that a high proportion of letter-writers were attached to official Soviet society. In September 1926, for example, the Kiev guberniia newspaper Molodoi Bol'shevik received 304 responses to a questionnaire sent to its youth correspondents (the paper calculated that it had just over 700 total correspondents). Of the respondents, $6.9 \%$ belonged to the Party, and a whopping $83.9 \%$ to the Komsomol. In addition $16.1 \%$ of respondents were village soviet members, $20.4 \%$ participated in local Komsomol "Youth Councils," 9.2\% were on the governing councils of local reading huts, $9.2 \%$ worked in rural cooperatives, and $8.6 \%$ belonged to Peasant Mutual Aid Societies. ${ }^{30}$

A local Siberian Komsomol paper, Molodaia derevnia, reported similar findings on its youth correspondents in late 1927. According to the newspaper's records, of 314 "regular" youth correspondents, 15 (4.8\%) were Party members, 35 (11.1\%) were Party candidate members, $206(65.6 \%)$ belonged to the Komsomol, and 58 $(18.5 \%)$ were not connected with either group. Of all youth correspondents, 206, or $65.6 \%$, were involved in some kind of "civic" work (connected with Soviet institutions, the Red Army, the Party, or the Komsomol; 176 correspondents (56.1\%) also wrote to other newspapers besides Molodaia derevnia and 213 $(67.8 \%)$ participated in the production of a hand-written "wall newspaper." 11

There is a very strong case to be made that between one-third and two-thirds of all who wrote letters to the Soviet press in the middle to late 1920s were members of Soviet official society (obshchestvennost') at one level or another. This is harder to argue for the 1930s because newspapers stopped doing studies of their readership or the social composition of the worker and village correspondents movement. However, scattered data exists. In August/September of 1930 Central Committee researchers reported to the Central Committee Secretariat that most "village correspondents" in their local surveys were young male Komsomol "cultural plenipotentiaries" - presumably the local youth activists assigned to organize cultural activities. ${ }^{32}$ In 1933 and 1936 the Central Committee attempted to reorganize the press distribution system in response to reports that most central newspapers circulated by institutional subscription to Party and Soviet officials, rather than the "laboring masses." 33 Assuming that the profile of letter-writers corresponded roughly to that of readers, then many correspondents must have been Party members and/or Soviet officials.

29. Iakov Shafir, "Chitatel' Rabochei gazety v tsifrakh," Krasnaia pechat', 26 (December 25, 1925): 37.

30. TsKhDMO, f. 1, op. 23, d. 590, 11. 32ob-33.

31. Ibid., d. 737a, 11. 29-30.

32. RTsKhIDNI, f. 17, op. 114, d. 197, 1. 98.

33. On these reform attempts, see M. Lenoe, Stalinist mass journalism, op. cit.: 177-179. 
In the late 1930s letter authors continued to include a disproportionate, though perhaps declining, number of members of official Soviet society. According to a Krest'ianskaia gazeta article cited by Sheila Fitzpatrick, of 1,784 letters received by the paper on two days in July 1935, "39\% came from rank-and-file kolkhozniki, $10 \%$ from kolkhoz chairmen and brigade leaders, $6 \%$ from journalists from local newspapers, 5\% from kolkhoz accountants and bookkeepers, 4\% from mailmen and telephone and telegraph workers, and $4 \%$ from teachers, agronomists and other 'local intelligentsia."'34 Thirty-two percent of the letters in the sample remained unaccounted for. Letters from groups clearly identifiable with obshchestvennost', namely the kolkhoz chairmen, work brigade leaders, local journalists, and "intelligentsia" such as schoolteachers, made up $29 \%$ of all letters accounted for in this survey. Assuming that all kolkhoz chairmen and brigade leaders were Party members, at least $15 \%$ of the writers were Communists, much higher than the percentage in the general adult population. At other newspapers the proportion of Communists, Komsomols, and other members of obshchestvennost' would have been considerably higher.

Other work by Fitzpatrick suggests that in Soviet society as a whole authors connected with official Soviet society continued to dominate the practice of letterwriting. In two recent articles on mail sent not just to newspapers, but also to Party leaders, prosecutorial organs, and other addresses, Fitzpatrick mentions 98 letters with authors who are identified by occupation and/or Party status. Of these 52, or $53.0 \%$, were written by persons who were either Communist Party/Komsomol members or connected with official society by profession (I include a historian, a statistician, a mathematician, and two engineers in this group). Although this is obviously not a random sample of correspondence, it does suggest that letterwriting continued to be predominantly a practice of Communists, Komsomols, and Soviet officialdom in the late $1930 \mathrm{~s} .{ }^{35}$

\section{Intelligence collection}

When Central Committee Agitprop Department officials moved to set up a central press network differentiated by audience (with a "mass worker newspaper," a "mass peasant newspaper," and a "leading" newspaper, Pravda, for the Party cadres) in the years 1922-1924, they also took steps to institutionalize the use of reader letters as a source of information on popular moods. The first steps in this direction were taken by editors at the Central Committee's new "mass" newspapers, Rabochaia gazeta and Krest'ianskaia gazeta in the early spring of 1924. In February S. B. Uritskii, a highly placed official in the Central Committee's

34. Sheila Fitzpatrick, "Readers' letters to Krest'ianskaia gazeta, 1938," Russian History, 24, 1-2 (Spring-Summer 1997): 149-170.

35. See Sheila Fitzpatrick, "Supplicants and citizens: Public letter-writing in Soviet Russia in the 1930s," Slavic Review, 55, 1 (Spring 1996): 78-105; "Signals from below: Soviet letters of denunciation of the 1930s," Journal of Modern History, 68, 4 (December 1996): 831-866. 
Agitprop apparatus and former editor of the railwaymen's trade union paper Gudok, wrote a letter of advice to Iakov Iakovlev, the editor of Krest'ianskaia gazeta, the new mass peasant newspaper. Uritskii, who had had much experience working with reader letters while at Gudok, emphasized the need to organize peasants from all over Russia to write in to the new paper. According to him, letters to Krest'ianskaia gazeta would help the Party to monitor popular mood in the countryside and alleviate the oppression of peasants by local officials. "Krest'ianskaia gazeta, the peasant megaphone, will play a colossal role; it will constantly correct our work among the peasantry. Krest'ianskaia gazeta, the barometer of peasant mood, will serve us in many ways and return our expenditures on it one hundred-fold." 36

Party authorities expected that the worker and village correspondents movement would provide them with information on popular moods. In April of 1924 Rabochaia gazeta, the Central Committee's "worker newspaper," held its second "All-Union" conference of its worker correspondents. The conference passed a series of resolutions on the tasks of worker correspondents and their role in society, approving of Rabochaia gazeta's organization of worker correspondents' "circles" at factories and workers' clubs. In a document entitled "Bylaws of Rabochaia gazeta worker correspondents' circles," the conference delegates noted the correspondents' duty "to register" the mood of workers, but also to "organize civic/ public opinion (obshchestvennoe mnenie)" in the interests of their class. ${ }^{37}$ From the earliest phase of the worker correspondents' movement, newspapers were charged with two different and sometimes contradictory tasks in work with reader correspondents. On the one hand, they were to solicit letters which "registered" popular moods; on the other they were to "organize" popular opinion.

By the time of Rabochaia gazeta's second worker correspondents' conference, Krest'ianskaia gazeta was already producing weekly summary reports on the themes of reader letters. On April 7, 1924, for instance, the newspaper's staff forwarded to the Agitprop Department a report on the themes of the 4,876 letters they had received between March 30 and April 7. The report laid out how many letters had come in on topics such as "taxes," "the exchangeable ruble," "forests," "complaints against the authorities," and so on. It also broke down the "social situation" of the letter-writers, indicating how many were Party members, Komsomol members, "advanced peasants," "illiterate peasants," and so on. ${ }^{38}$ Later, such reports would be presented in a different format, with a series of paragraph length quotations from reader letters. The numbers of letters on various themes was only presented sporadically, and the social background of their writers never (the

36. RTsKhIDNI, f. 17, op. 60, d. 892, 11. 21-22; d. 907, 1. 11. A special “worker correspondents' department" was set up at Gudok in late 1922 or early 1923. According to the newspaper's November 1923 report to the Central Committee, between 50 and $70 \%$ of each edition was devoted to reader letters.

37. RTsKhIDNI, f. 17 , op. 60 , d. 935, 11. 28-29.

38. RTsKhIDNI, f. 17, op. 60, d. 892, 11. 12-13. 
latter information was sometimes summarized in separate reports on "the social composition of the worker/village correspondents' movement").

Newspaper employees dealt with reader letters in three ways. Some letters, usually those which fit into one of the Party's ongoing propaganda campaigns, were published. Letters asking for information would be sent to an "Inquiries" or "Legal Consultation" department, while those making a complaint or accusation would be forwarded to the newspaper's letter investigation department, variously designated the "Department of Investigation," "The Worker/Village Correspondents' Department," or "The Bureau of Mass Work." Ideally, newspaper staff would find the answers to inquiries, sending them direct to letter-writers or publishing them in the paper, and forward accusations to appropriate police or prosecutorial organs. In reality many letters were simply discarded, archived, or lost. Of those which remained, some were utilized as a source of direct intelligence on popular opinions, moods and concerns. In this use of correspondence, employees of the letters department would read correspondence, prepare reports on its contents, and forward them to the newspaper editor, the newspaper's sponsoring institution, or other official instances.

The practice of using reader letters to produce reports on the attitudes of different social groups spread throughout the central Soviet press very rapidly. By 1926 Krest'ianskaia gazeta, the Central Committee's mass peasant newspaper, was forwarding weekly reports on reader letters to the highest level Party leaders. The editors of the Central Committee's mass worker paper, Rabochaia gazeta, and its "advanced" peasant newspaper Bednota, forwarded individual letters and probably summary reports to the leadership. Reports from the Komsomol's central organ, Komsomol'skaia pravda, reached both the Komsomol and Party Central Committees. As of early 1929, Pravda sent reports not just to the Central Committee, but also to the Commissariat of Agriculture and members of the Party Central Control Commission's Presidium. By the years 1927-1928, if not earlier, the major trade union newspapers were preparing reports based on reader letters for their respective trade union Central Committee. Among these were the railroad union's Gudok, the textile workers' union organ Golos tekstilei, the agricultural and forestry workers' union's Batrak, and the teachers' union newspaper Uchitel'skaia gazeta. Reports from the latter two newspapers reached the Party Central Committee apparatus as well as their own trade union central committees. The Moscow oblast' Party Committee received reports on reader letters from its own organ, Rabochaia Moskva, and some provincial Party organizations also appear to have received such reports from local papers. ${ }^{39}$

39. See RTsKhIDNI, f. 17, op. 85, d. 19, 11. 136-335 for 1926-1927 reports from Krest'ianskaia gazeta to the Party Central Committee. For letters forwarded from Rabochaia gazeta to Stalin, see RTsKhIDNI, f. 17, op. 85, d. 18, 11. 8-14, 29-30. For a 1930 reference to preparation of summary reports on popular mood at Rabochaia gazeta, see TsGAOD g. Moskvy, f. 190, op. 1, d. 7, 1. 81ob. See also RTsKhIDNI, f. 17, op. 85, d. 19, 11. 106-110 (Bednota to Stalin, 1926), RGAE, f. 7486, op. 37, d. 65, 11. 1-6 (Pravda to Commissariat of Agriculture, 1929), GARF, f. 374 s.ch., op. 28s., d. 2658, 11.402-403 (Pravdato TsKK, 1929), TsKhDMO, f. 1, op. 23, d. 587, 
During the second half of the 1920s, the highest ranking leaders of the Party, including Stalin, Molotov, Kaganovich and Bukharin, read the newspapergenerated intelligence reports and letters. This was a period of heightened anxiety for the Soviet leadership owing to a confluence of unrest at Moscow factories, a grain supply crisis, difficult decisions about industrial investment, and a series of foreign policy crises. Party leaders sometimes requested newspaper letter department reports on such "topical" (zlobodnevnye) issues as "peasant attitudes to the threat of war," or peasant complaints about the agricultural tax. Judging from these requests, and from the content of the intelligence reports themselves, the Party's leaders felt that foreign subversion, peasant resistance, intra-Party conflict, and the erosion of their base of support among factory workers actually threatened their rule.

Although intelligence on reader letters did reach the Party leaders, the channels it travelled were often jerry-built, and its processing ad hoc. Krest'ianskaia gazeta appears to have been the only newspaper regularly to forward intelligence reports to the Central Committee executive apparatus. If Party leaders wanted information on workers' attitudes, for example, they had to request it. Thus, during the industrial cost-cutting campaign of 1926, which provoked intense resentment in Moscow factories, Stalin got his intelligence on worker response from Rabochaia gazeta assistant editor Erlikh, who forwarded him selected reader letters and anecdotal accounts of conversations overheard by reporters. ${ }^{40} \mathrm{~A}$ brigade of Workers' and Peasants' Inspectorate investigators at the railway union organ Gudok in 1929 found that not only were many letters held up in processing for one to one-and-one-half months, but others were not read at all. Even though union Central Committee officials had recently been complaining of "poor informationprocessing," they did not take the newspaper's reports seriously. In the words of a letter department clerk, their attitude was, "as long as you're going to write them up, send them along." 41

Reader letters were not the sole source for the reports on popular mood reaching central authorities. Some reports were compiled from the anonymous written questions usually handed in to the orator at Party, Komsomol, or trade union meetings. Others were based on notes taken by Party agitators (agitators had to hand their notebooks in to the Party's Information Department at regular intervals) or the comments of informers working for the GPU.

11. 1-24 (Komsomol'skaia pravda to Komsomol TsK), GARF, f. 9613, op. 2, d. 94, 1. 1ob (Gudok to union TsK), TsGAOD g. Moskvy, f. 3, op. 9, d. 81, 11. 155-167 (Golos tekstilei to trade union TsK), RTsKhIDNI, f. 17, op. 85, d. 21, 11. 86-345 (Uchitel'skaia gazeta, Batrak, to Party TsK), TsGAOD g. Moskvy, f. 3, op. 9, d. 81, 11. 103-106 (Rabochaia Moskva to Moscow Party Committee). For a letter to the Kazan' newspaper Krasnaia Tatariia which made its way into a Party Information Department report on popular moods, see RTsKhIDNI, f. 17, op. 85, d. $217,1.22$.

40. RTsKhIDNI, f. 17, op. 85, d. 18, 11. 32-50.

41. GARF, f. 9613, op. 2, d. 94, 1. 1ob. 
The proliferation of intelligence reporting on popular moods through these clandestine methods was connected with a general contraction of the sphere wherein open expression of opinion was possible. Thus, in late 1923 and early 1924 the Central Committee's Agitprop Department followed the course of the conflict between Trotskii and "the triumvirs" (Stalin, Kamenev, and Zinov'ev) in the provinces by excerpting editorials from local newspapers and combining them in reports on "the Party discussion." 42 Because local Party organizations had not yet internalized the rules against "factionalism" adopted by the X Party Congress in 1921, many provincial papers ran discussions and editorials on the conflict. These served the Agitprop Department as sources for the state of opinion within the Party. By 1926 newspapermen were much more circumspect about openly questioning the Central Committee's "general line," making the newspapers unsuitable as a source of information on the real state of Party opinion. The contraction of the sphere of open discourse made the Party's intelligence-gathering task more difficult. To put the problem another way, the Bolsheviks made their own intelligence operations more difficult by limiting freedom of the press.

The Party was very concerned about keeping intelligence reports on popular mood secret. This was also an aspect of the contraction of space available for open expression of opinion. It is unclear what fear lay behind the anxiety to conceal the existence of the reports from the general population - whether Party leaders did not want people learning of opposition to Soviet power through any channel whatsoever, or whether they did not want people to know that they were under surveillance. For whatever reason, newspaper employees were sometimes censured for leaving reports lying around on desks. In the eyes of Party leaders one of most heinous crimes of the Trotskii-Zinov'ev Opposition was disseminating reports on popular mood to workers and other ordinary citizens. ${ }^{43}$

In the Moscow archives open to foreign researchers newspaper reports on public moods nearly disappear after 1933. In my own extensive search of the open Central Committee files, I found no such reports dating from after 1929 with the exception of a few from Krest'ianskaia gazeta on the 1936 discussion of the new Constitution. As of 1932 the Commissariat of Agriculture was still receiving newspaper intelligence reports, as was the railwaymen's trade union Central Committee in 1933. I found no later newspaper intelligence reports in Moscow archives, although admittedly my search for the 1930s was less thorough than for the 1920s. Professor Andrei Sokolov, who first pointed out this gap in the documentation to me, suggests that the regime no longer required information on popular mood (he used the phrase obratnaia sviaz', meaning a channel for "messages" from the populace to the regime leadership) after Stalin's revolution from above, and so the practice of producing such reports died out. It did not die out completely, however, for

42. RTsKhIDNI, f. 17, op. 114, d. 871, 11. 3-22.

43. On the dissemination of svodki to workers as a crime against Party and state, see RTsKhIDNI, f. 17, op. 85, d. 207, 11. 9-13. For an example of a reprimand issued to Rabochaia gazeta employees for leaving svodki lying about the office where non-Party members could see them, see TsGAOD g. Moskvy, f. 190, op. 1, d. 7, 1. 81ob. 
between 1953 and 1961 Pravda forwarded reports on reader letters to Khrushchev, and in 1966 the newspaper Sel'skaia zhizn' sent a report on reader letters about hooliganism to the Central Committee. ${ }^{44}$

I would like to propose two hypotheses about the use of reader letters as a source of intelligence on popular moods. Both of them should be testable by further archival research. First, I suggest that after 1930 or thereabouts the Central Committee leaders no longer made much use of newspaper reports on popular moods. Such reports may not disappear entirely from the Central Committee's files, but they should appear with much less frequency. Second, I propose an alternative to the hypothesis that the regime no longer needed information on popular moods because its repressive apparatus had grown so strong. Soviet leaders did feel a need for information on popular moods, but that they came to depend on other sources which they considered more reliable, namely OGPU reports based on intelligence from informers.

In this scenario, the Party would have once again created its own intelligencegathering problem by squeezing the sphere of open expression of opinion. It could have done this in at least two ways: by prosecuting letter-writers who wrote to papers with "anti-Soviet" missives and by increasing its control over regular "worker/peasant correspondents." This hypothesis should also be verifiable — one would expect to find evidence in central files after 1930 that Party leaders were reading fewer reports based on letters to the press, and more OGPU reports. One might also expect a concomitant increase in the size of the OGPU's informer network. I do not suggest that svodki based on reader letters to the newspapers disappeared after 1933 - only that Party leaders came to rely less on them and more on intelligence from OGPU informers. ${ }^{45}$

Reader letters were problematic as sources of intelligence because their authors were writing to authority. Letter-writers who openly opposed the regime sometimes stated their expectation that the authorities would turn their letter over to the OGPU. 46 Obviously the fear of prosecution would affect both the tone and content of letters to the newspapers, and at least some Party higher-ups were aware of this difficulty. In October 1926 Iakov Iakovlev, the editor of Krest'ianskaia gazeta and Commissar of Agriculture, forwarded Krest'ianskaia gazeta's monthly report on the content of reader letters to Central Committee Secretary Molotov,

44. Nicolas Werth, Gaël Moullec, eds, Rapports secrets soviétiques, 1921-1991 (Paris: Gallimard, 1994): 50, 169, 618.

45. On the basis of fragmentary but suggestive evidence Vladlen Izmozik argues that the Cheka/OGPU's informer network expanded rapidly in the second half of the 1920s. At the end of 1924 the OGPU had about 10,000 paid informers throughout the Soviet Union, including 518 in Moscow. Two years later there were over 10,000 paid informers in Moscow alone, according to G. S. Agabekov, an OGPU agent who defected in 1930 (V. Izmozik, op. cit.: 112, 117). Another measure of the OGPU's activity which might bear indirectly on the question of the size of the informer network is the number of detainees brought to trial. In 1924 the OGPU brought 12,425 to trial; in 1929, 33,757 (ibid.: 120-21).

46. See, for example, a Kiev Trotskyite's letter to the newspaper Proletarskaia pravda in RTsKhIDNI, f. 17, op. 120, d. 18, 1. 25. 
accompanied by a scribbled note, which read in part: "It's too bad that we can't use anonymous letters, as these are the most topical (I am sending you a report on the anonymous correspondence in any case) [...] Greetings, Iakovlev." (Italics are mine - M. L.) Iakovlev was well aware that the anonymous letter-writers were more frank than those who signed. ${ }^{47}$

After 1930 greater fear of repression and Party activists' increased efforts to use worker/peasant correspondents to "organize" rather than "register" "public opinion" (obshchestvennoe mnenie) trammeled letter-writers' frank expression of their opinions. The sphere wherein one could express one's own political opinions without fear of persecution had narrowed to circles of personal friends. Very few people could be expected to express themselves openly to authority. To get even approximately accurate intelligence on the mood and attitudes of the population, the Soviet leaders would have had to resort to sources which "tapped" private communications, by perlustrating personal letters and building networks of informers.

The Soviet authorities' dominating interest in information on opposition to their rule also complicated the use of reader letters as an intelligence source. Persons writing to authority must have become more and more reluctant to express opposition to the regime as the 1920s wore on, yet Party leaders wanted to read precisely that. In 1929 a standard disclaimer appeared on Pravda letter department reports, stating that the intelligence therein did not reflect popular mood as a whole, but specifically negative attitudes toward the Party and Soviet power. In short, the Party was primarily interested in gathering information on oppositional moods. The persons preparing reports on reader letters were aware of the bias this introduced to their reports and wished to warn the authorities about it. But except for anonymous missives, after 1930 letters to the newspapers must have been an increasingly poor source of statements of opposition to the Bolsheviks or the Central Committee's "general line."

To what extent did such intelligence reports influence the conduct of Party and Soviet authorities? Evidence from the mid-to late 1920s suggests their influence was quite weak. Bolshevik practices and political culture affected the processing and interpretation of intelligence so that neither would contradict the Party leaders' ideological assumptions or their sense of the acceptable range of policy options. At the level of information processing, the authorities demanded intelligence on opposition to Soviet power, and they got it. Whatever the popular attitude toward the regime, the men and women working in the newspaper letter departments were expected to unearth evidence of opposition, and they did. Also at the processing level, the Party leaders determined what issues would be reported on. To a large extent, they set the agenda for the reports on reader letters by requesting information on on-going Party propaganda campaigns and other issues of concern. In 1926 this meant the industrial cost-cutting campaign, in 1927 the threat of war with England and the struggle with the Trotskii-Zinov'ev Opposition, in 1930 the 
collectivization campaign, in 1933 rationing to workers, in 1936 the discussion of the new Constitution.

Party leaders' ideological preconceptions affected their interpretation of intelligence. Between 1926 and 1929, for example, the prevailing interpretation of letters opposing Soviet power was that they reflected the politically immature, "unconscious" attitudes of ignorant peasants and the "petty bourgeois" mores of artisans and the "vulgar," "declassed" urban masses - clerks, casual day laborers, telephone operators, shop girls and the like. The complaints and problems of the populace were thus reduced to the proposition, "class determines political consciousness." The letters then became nothing more than an indication that the Party needed to press forward even faster with its project of industrializing the USSR and turning the various backward segments of the population into forwardthinking proletarians. This kind of thinking enabled the Central Committee leaders to dismiss a long compilation of peasant complaints about the injustice of the agricultural tax in kind submitted to Molotov by Krest'ianskaia gazeta's "Legal Consultation" department in 1927. In his introduction to the report, the head of the department, Mazel', offered Molotov a ready-made explanation for the peasants' angry attacks on the tax and its administration. "The complainant in most cases is not in a condition to understand what the situation is, he complains exclusively about the [tax's] effect [...] but the basic reasons which create this effect, so unpleasant for him, are beyond his understanding." To paraphrase, peasants were too ignorant to understand the necessity of paying taxes. ${ }^{48}$

In the years 1926-1928 newspaper intelligence reports showed a high degree of discursive instability in Soviet society. In particular peasants and lower level Party activists were not getting the Party's message. In a file of over 500 letters collected by Krest'ianskaia gazeta on the Trotskii-Zinov'ev Opposition, for example, 23.9\% of writers opposed or doubted the Central Committee's "general line." Elsewhere I have argued that the discursive instability revealed in reader letters helped catalyze the transformation of the tone and content of the Soviet press which occurred between 1927 and 1930. From a relatively nuanced presentation of Party policies, the central Soviet newspapers switched over to shrill, emotional attacks on "class enemies." These attacks were designed to appeal to relatively uneducated, semiliterate readers, to mobilize them against real or imaginary enemies with angry rhetoric they would understand. Reader letters did contribute to this change, but they did so only by reinforcing the preconceptions of certain powerful Party leaders and newspaper editors (notably Stalin, Kaganovich, Molotov, and Rabochaia gazeta editor Nikolai Smirnov) that worker and peasant audiences were simple-minded and only able to understand appeals to class hatred and envy. The gut-level emotional convictions of Party leaders were at least as important as "objective" intelligence in determining the "dumbing down" of the Soviet central newspapers. 49

48. Ibid., 1. 149.

49. Matthew Lenoe, "Reader response to the Soviet press campaign against the Trotskii-Zinov'ev Opposition, 1926-1928," Russian History/Histoire russe, 24, 1-2 (Spring-Summer 1997): 89-116. 


\section{Denunciation and monitoring the state apparatus}

Like the worker and village correspondents movement and the preparation of reports on popular moods, the use of denunciatory letters ("signals from the localities") to monitor the state apparatus was institutionalized in the years 19231924. Although Party leaders had discussed using worker correspondents to expose corruption and incompetence in the bureaucracy during the Civil War, it was only in the third year of the NEP that central "mass newspapers," such as Rabochaia Moskva and Rabochaia gazeta set up their own "Investigative Bureaus" which handled denunciatory letters. ${ }^{50}$ At these bureaus employees sorted letters and forwarded those they deemed actionable to appropriate authorities for further investigation. Typical destinations included the Moscow guberniia state prosecutor's office, the GPU, the Ministry of Internal Affairs (NKVD), the Workers' and Peasants' Inspectorate, or the Central Control Commission, the organization responsible for purging the Party of malcontents.

By 1925 the practice of forwarding denunciatory letters to local prosecutors' offices was well-established, at least in Moscow guberniia. For that year the guberniia prosecutor's office reported opening 801 investigations based on letters sent to Moscow newspapers. Of this total 208, or over one-quarter, dealt with beskhoziaistvennost', a catchall term for financial mismanagement. The number two and number three categories were embezzlement by officials (109 cases) and violations of labor laws (104 cases). According to the prosecutor's office 268 of the letters, or $33.5 \%$ of the total, were forwarded by Rabochaia Moskva, 112 (14.0\%) by the guberniia's peasant newspaper Moskovskaia derevnia, 111 (13.9\%) by Pravda, 104 (13.0\%) by Rabochaia gazeta, and 206 by other papers. As of March 1926 investigation was complete in 408 of the 801 cases from 1925. Of these the prosecutor had confirmed charges made by worker correspondents in 273 cases, or $34 \%$ of the total. ${ }^{51}$

As Sheila Fitzpatrick points out in a recent article on Soviet denunciations in the 1930s, a writer often sent the same denunciatory letter to a number of different agencies at once. This was because, Fitzpatrick notes, "there was really no

50. On Lenin's 1918 article, "On the character of our newspapers," which urged newspapermen to "expose the unfit" and unmask the "actual malefactors" who disrupted production and political work, see Peter Kenez, The birth of the propaganda state. Soviet methods of mass mobilization, 1917-1929 (Cambridge: Cambridge University Press, 1985): 49. The VIII Party Congress, meeting in March 1919, also endorsed the use of worker and village correspondents to monitor the bureaucracy and expose abuse of power (see $O$ partiinoi $i$ sovetskoi pechati: sbornik dokumentov (Moscow: Izdatel'stvo "Pravda," 1954): 212). On the investigatory bureaus at Rabochaia gazeta and Rabochaia Moskva, see "Revoliutsionnaia zakonnost' i rabkory. Prokuratura i rabkorovskoe dvizhenie," Put' rabsel'kora, 1 (March 15, 1926): 9-10. The Moscow guberniia prosecutor's office reported receiving denunciatory letters from both these papers, as well as Pravda, Moskovskaia derevnia (the guberniia peasant paper), and other organs. By 1923 Gudok also had a "Worker Correspondents' Bureau" and was instructing its correspondents to expose "shortcomings," describing when each incident occurred, why it occurred, and who was responsible (see RTsKhIDNI, f. 17, op. 60, d. 907, 1. 4).

51. "Revoliutsionnaia zakonnost' i rabkory...," art. cit.: 9-10. 
substantive difference between sending a denunciation to a newspaper and sending it to the NKVD or some other official agency." 52 The practice of writing denunciatory letters to the press can be treated by the historian as continuous with that of writing to public prosecutors, the secret police, or even Stalin himself.

Fitzpatrick points out that letter-writers often manipulated the practice of denunciation for their own benefit. An ambitious peasant might denounce the chairman of his collective farm in hopes of becoming chief himself. Scholars denounced their opponents within academe for political crimes or other offenses. People of all social strata would denounce neighbors in hopes of getting hold of their apartments (Fitzpatrick recognizes this as an entire genre in itself - "the apartment denunciation"). ${ }^{53}$ In all of these cases an individual or individuals attempted to utililize the state's surveillance mechanisms for their personal gain.

Just how "vulnerable to manipulation" was the Soviet state? One measure of this is the percentage of denunciatory letters that resulted in disciplinary or judicial action against the denounced. Fitzpatrick cites Krest'ianskaia gazeta's claim in 1935 that as the result of 746 letters sent to outside investigative organs, 103 persons had been "dismissed, prosecuted, or otherwise punished, and in 110 cases the accusations had been found to be groundless." 54 Roughly speaking, one in seven letters eventually elicited punishment of the denounced. However, this estimate does not include the first "filter" that letters passed through - the newspaper's letter department. We do not know how many letters of denunciation the department received but did not forward for investigation.

Scattered figures from other papers indicate that Krest'ianskaia gazeta's punishment rate was probably on the high end of the scale. Different newspapers handled letters with varying degrees of care. In early 1929 Gudok, for example, received 500 to 550 reader letters per day, of which about 170 were channeled to the Bureau of Investigation. Approximately one-third of all letters received, then, were denunciations of one "disorder" or another. ${ }^{55}$ In the first three months of 1929 Komsomol "raiders" reported that between 10 and $14 \%$ of all letters received by Gudok were "sent on for investigation." This would be approximately 50 to 75 letters per day, or, in round numbers, 30 to $45 \%$ of the 170 denunciatory letters. ${ }^{56}$

As we have seen, Krest'ianskaia gazeta reported that in 1935 about one in seven denunciatory letters (14\%) forwarded to investigative authority resulted in punishment for the denounced. Assuming that Gudok had a similar rate in 1929, then the percentage of all denunciatory letters which elicited punishment of their

52. S. Fitzpatrick, "Signals from below...," art. cit.: 835.

53. Ibid.: 853-856. Fitzpatrick cites three "apartment denunciations" in this article.

54. Ibid.: 859. The quotation is from Fitzpatrick.

55. This squares well with Golfo Alexopoulos' finding, cited in S. Fitzpatrick, "Readers' letters...," art.cit., that $31 \%$ of the letters in a single opis' of the Krest'ianskaia gazeta archive (1938) were denunciations of "abuses." It does not, however, square so well with Krest'ianskaia gazeta's report in July of 1935 that only $11 \%$ of letters were denunciations (also cited in S. Fitzpatrick, "Readers' letters").

56. GARF, f. 9613, op. 2, d. 94, 11. 2-2ob. 
targets would be between $30 \%$ X $14 \%=4.2 \%$ and $45 \%$ X $14 \%=6.3 \%$. Perhaps one in twenty denunciatory letters sent to Gudok $(5 \%)$ ultimately hit its target.

The scattered numbers available corroborate the data from Krest'ianskaia gazeta and Gudok, and imply that rates of investigation and punishment on denunciatory letters were comparable from the mid-1920s to the mid-1930s. For example, statistics on the disposition of denunciatory letters are available for Izvestiia's Investigative Bureau for the three months from November 1926 through January 1927. In February 1927 the newspaper's editorial staff reported channeling 2,596 letters to the Investigative Bureau. Nearly all of these presumably involved denunciations, because other types of letters were sent to other departments (most went to the Legal Consultation Department which handled 2,848 legal inquiries during the same time period). Of the 2,596 presumed denunciations, the Investigative Bureau reported actually looking into 780 cases, or $30 \%$. As of January 25,1927 , these cases had resulted in the exposure of 73 "crimes," ranging from murder to "shortcomings in the Soviet apparatus." As of this date, then, 2,596 denunciatory letters had resulted in some form of punishment for the accused in 73 cases, or $2.8 \%$ of the total (included in the category "punishment" are 22 cases which were simply publicized in the newspaper and 20 in which "claims were satisfied"). Of the 708 forwarded letters, about $9 \%$ resulted in some punishment for the accused. An additional 145 letters had been sent to outside prosecutorial organs for further action. Even assuming that every one of these 145 cases resulted in punishment for the denounced, 218 out of a total of 2596 letters (8\%) would have hit their target. ${ }^{57}$

In 1928 and 1929 the Rostov-na-Donu paper Molot also claimed to investigate about one-third of all denunciations received, the same proportion as Izvestiia and Gudok. According to a report in the Central Committee's trade journal for newspapermen, Zhurnalist, the Bureau of Investigation at Molot received about 22,000 letters between May 1928 and May 1929. Of these the Bureau looked into 8,500 , or $39 \% .58$ Other papers seem to have investigated a much lower proportion of denunciations received. For example, the Moscow oblast' peasant paper Moskovskaia derevnia in 1925 and 1926 sent out only $4.5 \%$ of all letters received for investigation. Assuming that approximately one-third of the paper's correspondence was denunciations (this proportion seems to have been fairly constant for Soviet papers in this period), then Moskovskaia derevnia was forwarding only $14 \%$ of such letters for investigation. ${ }^{59}$

57. GARF, f. 1244, op. 1, d. 22, 1. 15.

58. Zhurnalist, 4 (February 1930): 127.

59. Put' rabsel'kora, 17-18 (November 30, 1926): 7-8. At about the same time Rabochaia Moskva reported investigating only 280 out of 2,429 letters received. Assuming that one-third of these were denunciations (810), then the newspaper was investigating $35 \%$ (see Put' rabsel'kora, 13 (September 15, 1926): 31. For many newspapers the proportion of all correspondence which was denunciations was about one-third. Gudok reported this proportion in 1929. Golfo Alexopoulos found that 50 out of 162 files (31\%) from the Krest'ianskaia gazeta archive for the year 1938 included denunciations (see S. Fitzpatrick, "Readers' letters...," art. cit: 8$)$. 
Data from the years 1924-1935 suggests, then, that newspapers in the decade between 1925 and 1926 were forwarding between 14 and $40 \%$ of the denunciatory letters they received to investigative organs. At Izvestiia in 1926-1927, $9 \%$ of all forwarded letters resulted in punishments; at Krest'ianskaia gazeta in 1935 the corresponding number was $14 \%$. Assuming a high forwarding rate of $40 \%$ and a high punishment rate of $14 \%$ on forwarded letters gives a net punishment rate of $6 \%$ on all denunciatory letters. Overall punishment rates may have been well under $5 \%$.

As Fitzpatrick points out, writing a denunciation was like playing the lottery. Given the relatively low chances of success, skepticism is warranted about claims that writers of manipulative denunciations were commandeering the state apparatus for their own personal purposes. The state's agents were, rather, commandeering personal interests in the service of their agenda of surveillance, control, and political education. Soviet subjects who denounced their fellows strengthened the state's surveillance mechanism. When they wrote their denunciation, they had no idea if it would bring any positive results, or if it might even rebound against them. Investigations were conducted in secrecy, jurisdictional boundaries between prosecutorial organs were unclear, and neither denouncer nor denounced had clearly defined rights of appeal. When combined with the Bolshevik mania for secrecy, bureaucratic chaos actually contributed to the state's dominance of its subjects by making the process of investigation opaque.

Numerous reports on newspaper handling of letters show how disorganization and staff inability to deal with a high volume of correspondence contributed to the "lottery" aspect of denunciation. At Gudok in 1929 a brigade of Komsomol investigators reported that processing of letters was often delayed for one to oneand-one-half months. Just over two-thirds of letters were simply thrown out (zabrakovano). The brigade found many unread letters in the files of Gudok employees. ${ }^{60}$ At Izvestiia the Bureau of Investigation explained in an early 1927 report that relatively few denunciatory letters were confirmed because such letters were forwarded to prosecutorial offices, where they were in turn forwarded to "lower level organs which are often careless."61 A 1934 article in the Central Committee's trade periodical for journalists, Bol'shevistskaia pechat' scourged the provincial paper Gorkovskaia kommuna for its careless handling of reader letters, especially denunciations. The article described how secretaries at the paper simply threw away a letter denouncing local officials who had closed a workers' club. Those "guilty" of closing the club were only punished after the denouncer sent a copy of the letter to a local paper. Bol'shevistskaia pechat' claimed that from the entire year of 19334,000 letters remained formally classified as "under investigation," but at least half of these were in fact lost. ${ }^{62}$

60. GARF, f. 9613 , op. 2, d. 94 , 11. 2-2ob.

61. Ibid., f. 1244, op. 1, d. 22, 11. 17-19.

62. Bol'shevistskaia pechat', 2-3 (February 1934): 44-45. For further descriptions of newspaper editorial office mishandling of reader letters, see Zhurnalist, 4 (February 1930): 122; 11-12 (June 1930): 31. 
A paradox characterized the Party press' handling of reader correspondence and the worker/village correspondence movement. Party leaders and agitprop officials pressed newspapers to supervise correspondents closely, answer every single letter received, and follow up on denunciations and complaints. Yet the processing of correspondence was often haphazard and chaotic. The secretaries handling letters were often overwhelmed by the volume of correspondence. A denouncer's chance of eliciting punishment of the denounced was only one in ten or one in twenty. From the point of view of the letter author this chaos made denunciation a roll of the dice, not a legal process with well-defined stages and channels of appeal. The net effect must have been to induce a sense of powerlessness vis-a-vis the state. From the point of view of higher-level agents of the state, this chaos may not have been desirable, but neither did it disable the mechanisms for "enlightenment" and surveillance of the populace.

Persons who denounced local officials to higher authorities were forced to speak in the language of the Soviet state, couching their accusations in Bolshevik terms. To accuse corrupt officials of being former kulaks, priests, Mensheviks, or other "class enemies," denouncers had to learn the language and ideological categories of Bolshevism. In writing up their accusations, denouncers only strengthened the Bolshevik ideological monopoly in written communication. By repeating Bolshevik categories, metaphors, and rhetoric in their letters, denouncers demonstrated and reinforced the power of the Soviet state. In addition to political control, then, denunciation fulfilled functions of "enlightenment," in the sense of propagating the tenets of Bolshevism.

A February 1934 article, "The worker and village correspondents' movement at a new level," in Bol'shevistskaia pechat' celebrated this process. According to this piece, the "political content" of correspondents' letters had recently become more sophisticated. In the past, it explained, correspondents had focused on "trivial facts," "their own personal issues," but now more of them denounced "distortions of the Party line," discussing life on the collective farms in terms of the tasks set by the state, and analyzing "the root" of local disorders using Marxist-Leninist categories. Bol'shevistskaia pechat' cited the exemplary development of one collective farm worker, Matrena Chernysheva, a 50-year-old woman who had begun writing to the newspaper in 1930.

"At first she wrote that the collective farm chairman had gone to town on one of the farm's horses to buy wine. Now she writes that the class enemy in the collective farm is growing stronger, that he is stealthily destroying the collective farm (her own expresssion) and etc. She writes that the class enemy relies primarily upon the collective farm's horse, that the horse has been 'appropriated.'”63 


\section{Petitioning for benefits}

Along with surveillance, education, and control of the state apparatus, a fourth important function of letter-writing in Soviet society was adjusting the state's distribution of goods and favors. Petitions for increased salaries or rations, the restoration of political rights, or the reversal of some administrative decision were common letter genres. These requests smoothed the functioning of the state's central distribution mechanism, warning officials which groups might be dissatisfied with their share of the pie. Soviet newspapers, especially trade union organs, provided readers with information on rationing categories, wage scales, disability insurance, and other forms of state-dispensed benefits. Readers in their turn wrote to the newspapers to request further information on their entitlements or petition for an upgrade. These practices were part of the establishment of a "hierarchy of consumption" (Elena Osokina's phrase) in the Soviet Union in the late 1920s and the early 1930s. During this period higher Bolshevik authorities used their control over legal distribution mechanisms to channel salary funds and goods of all sorts to favored social groups - Party members, Red Army units, skilled factory operatives, the GPU, and technical specialists. Reader letters to the newspapers were an integral part of the functioning of this hierarchy of consumption. ${ }^{64}$

The archive of the railwaymen's trade union organ Gudok bulges with requests from union members for benefits information and/or upgrades. These are a valuable and as yet unutilized source on the functioning of the Soviet rationing and distribution systems and their effects on the psychology of ordinary Soviet subjects. The letters reveal a workforce fragmented by resentment of those higher in the "hierarchy of consumption," frightened by the specter of starvation, frustrated by powerlessness in the face of management abuses, and ready to blame "wreckers" among local officials for their difficulties. In many cases the newspaper appears to have been the workers' only avenue of appeal against exploitation and injustice.

A typical letter came from a group of information booth attendants employed at Leningrad's Vitebsk railroad station. It was dated May 30, 1934. The agents complained that their pay and rations were too low given the difficulty of their job, which involved dealing with irate or frantic passengers, knowing the railway's regulations and fares, and memorizing railroad maps. They protested that they made only 113 rubles 52 kopecks per month with a second-category ration card, while cashiers in the "Commercial Department," whose job required "no special qualifications," were paid 150 rubles. On these wages, they wrote, they could not physically sustain shouting into the telephone for eight hours a day. Although the agents had petitioned the Commissariat of Transportation for a raise to 150 rubles per month, citing a Commissariat administrative order from 1929 which entitled

64. On the "hierarchy of consumption," see Elena Osokina, Ierarkhiia potrebleniia (Moscow: Izdatel'stvo MGU, 1993). 
them to pay in the "highest qualified" category, their request had been turned down. They now asked Gudok to pursue the matter. ${ }^{65}$

The paper's letters department forwarded the agents' complaint to the railway workers' union Central Committee together with a standard form requesting an investigation. The union Central Committee in turn notified the information booth attendants in Leningrad that it was not possible to raise their wages, given a freeze in wage levels ordered by "directing organs," presumably the Commissariat of Transportation. 66

Pravda forwarded a similar complaint to the Gudok letter department on July 22, 1933. In this letter a mechanic named N. I. Fadeev who repaired watering equipment at the Vereshchagino station in Perm province asserted that unskilled laborers at his depot were making higher wages than he was. After Gudok forwarded this protest to the railwaymen's labor union, the union Central Committee (TsK) sent a reply to Fadeev informing him that nothing could be done until the general wage contracts were made up for 1934. Then, the TsK stated, the issue of wage scales for different occupational groups would be reviewed. Like the information booth attendants, Fadeev voiced resentment of another occupational group making more money. He also made a similar appeal to written regulations, but as in the attendants' case, this was in vain. ${ }^{67}$

In some cases, however, action was taken to redress an injustice. In October 1933 locomotive mechanics based in Simferopol' wrote to Pravda with a complaint that they had never received prize money for winning a nationwide competition for "best shock-worker/mechanics' brigade." The mechanics suspected that their brigade leader, Shamara, had embezzled the prize money, but Gudok investigators found that payment was held up inside the railwaymen's union Central Committee apparatus. The paper then published a story on the incident calling for the Central Committee to punish "those workers who have a bureaucratic attitude towards shock work and socialist competition, and to ensure immediate payment to the mechanics' brigade [...]." 68

Growing frustration with delays in wage payments and breakdowns in the distribution system made railroad workers ripe for the scapegoating of local officials as "wreckers." Five workers from Lebiazhev Station in Perm province wrote a short piece to Gudok entitled "Who is responsible for this?" The letter ran in part as follows

"At Lebiazhev Station this is what is happening with supply of the workers. During March we did not receive our rations. Only one-quarter of the allotment was distributed to the workers. The head of the Party Committee blames it on the higher administrative organs, but they give us no answer. We are getting ten

65. GARF, f. 9613, op. 2, d. 93, 11. 4-9.

66. Ibid., 11. 1-1ob.

67. Ibid., d. 89, 1. 1-2.

68. Ibid., 1. 99ob. 
kilograms of flour per month for each worker here, and for the wife and children - four kilograms. How can a worker live? At least they might give it to us on time. We ask the editors of Gudok to send a brigade to us to investigate who it is who is wrecking. It's a bad business." 69

In 1933 the Central Committee of the railwaymen's union was very concerned with the effect of supply breakdowns on workers' morale. The Gudok letters department forwarded regular reports on "letters of railroad workers on the supply situation." As with other reports on popular moods, these were supposed to be secret, and were marked "Confidential" (ne podlezhit oglasheniiu). These reports were a litany of complaints about delays in wage payments, low salaries, inadequate rations, and denunciation of other occupational groups who were better paid or supplied. Lurking in the background was a real fear of starvation. In a typical letter excerpted for one report, switchmen demanded transfer from category three to category one rations.

\footnotetext{
"We receive ten kilograms of flour, plus four for our family, and besides what there is in the [worker] cafeteria, nothing more. It is impossible to live. Workers with big families already have swollen bellies. We asked the county (raion)TPO to put us in category two at least, but they told us they couldn't. How to continue? A switchman gets 48 rubles and even that is late. April is already nearly over, and we still don't have our March salaries. We, the switchmen, ask Gudok to advise us how we are to survive (kak nam dal'she zhit')."70
}

Petitions to Gudok regarding wages, benefits, and rations are a rich source for the study of central distribution mechanisms in the early USSR and their effects on the psychology of Soviet subjects. Whether deliberately or inadvertently, the Party's establishment of a hierarchy of consumption seems to have fragmented the workforce into a large number of different occupational groups competing for bigger handouts from the state. Breakdowns in supply as well as malfeasance by enterprise managers and local officials frustrated workers and made them tinder for agitprop campaigns scapegoating lower level authorities for shortages and other systemic problems.

As with other genres of letters, petitions for improved pay or benefits are an excellent source for studying the relationship between rulers and ruled, between the agents of the state and their subjects. They reveal how the Soviet state's centralized distribution mechanisms shaped the attitudes of Soviet subjects towards political authorities and other occupational groups. The resentment, jealousy, and fear thus generated (whether deliberately or not) primed the populace to accept scapegoating campaigns against middle-level officials and other "enemies of the people."

69. Ibid., 1. 239.

70. Ibid., 1. 236. 


\section{Conclusion}

Scholars to date have taken two distinct approaches to reader letters and the practice of letter-writing. Sheila Fitzpatrick and Sarah Davies have emphasized letterwriters' manipulation of the state for their own purposes, their attempts to lay claim to certain legal rights, their employment of official rhetoric in subversive contexts, and their persistent use of "traditional," prerevolutionary cultural categories. In short, Davies and Fitzpatrick see the letters as sites of resistance to and exploitation of the state apparatus. It is incontestable that some letter-writers did try to manipulate the state, did subvert official rhetoric, and did lay claim to legal rights. ${ }^{71}$

The letters, however, must be used with caution in any attempt to gauge readers' "real" opinions independent of official ideology. Two strategies are possible, and to their credit Fitzpatrick and Davies employ them. In her Popular opinion in Stalin's Russia, Davies "triangulates," taking her bearings not just on reader letters to authority, but also on sources tapping more private communications, in particular Party and NKVD intelligence based on informers' reports. Fitzpatrick does the same in her recent study of collective farms under Stalinism, Stalin's peasants. Both Fitzpatrick and Davies also employ a second strategy, seeking anomalies in the letters - words or phrases which were not part of official discourse, or important elements of official discourse which are missing from the letters. Fitzpatrick, for example, notes the "infrequency of even a perfunctory bow to the Stalin cult" in peasant letters to Krest'ianskaia gazeta in 1937-1938, citing it as evidence of peasant hatred of the dictator. ${ }^{72}$ Davies observes that some letterwriters in the later 1930s used the word batiushka, a prerevolutionary apellation for the Tsar which never appeared in official discourse, to refer to Stalin. This suggests that "traditional" prerevolutionary attitudes toward patriarchal authority persisted into the late 1930s. ${ }^{73}$

The second approach to reader letters follows the way in which Party officials, newspapermen, and other agents of the Soviet state used letter-writing as a tool to shape the public identity of Soviet subjects. Scholars who have taken this route include Jeffrey Brooks, Michael Gorham, and Steven Coe. ${ }^{74}$ All three authors discuss the role of the worker and village correspondents movement in the education of Party activists and a new Soviet intelligentsia. Coe also devotes space to the processing of denunciations by Krest'ianskaia gazeta. But the other aspects of letter-writing as an instrument of state power - the collection of intelligence on

71. See Sarah Davies, Popular opinion in Stalin's Russia (Oxford: Oxford University Press, 1997); S. Fitzpatrick, "Signals from below...," art.cit.; id., "Supplicants and citizens: public letter-writing in Soviet Russia in the 1930s," Slavic Review, 55, 1 (Spring 1996): 78-105; id., "Readers' letters...," art. cit.; id., Stalin's peasants (Oxford: Oxford University Press, 1994).

72. S. Fitzpatrick, Stalin's peasants, op. cit.: 295.

73. S. Davies, op. cit.: 158.

74. See Jeffrey Brooks, art. cit.; S. Coe, op. cit.; M. Gorham, art. cit.: 412-429. 
popular moods and the adjustment of distribution mechanisms — have not yet been examined. ${ }^{75}$

The study of letter solicitation and letter-writing as a tool of state power deserves attention. Certainly the practice involved an element of compromise/ contest between authors and state officials, as for example when the Party adjusted its agitprop campaigns based on the content of letters, or when Gudok published an article attacking labor union officials for failure to pay prize money to a brigade of shock workers. But in the end the relation between state and subject was radically assymetrical. It was agents of the state who defined the terms of discussion, decided which letters would be published, and determined which denunciations to act upon. A Soviet subject who wrote to the newspaper with an opinion about Party policy or a denunciation of some local "disorder" provided information useful to the state but had no guarantee of meaningful official action in response. When letter authors expressed opinions about policy, Party response, if any, was generally limited to changes in the tone or content of agitprop campaigns. Letters to the newspapers were not part of a public exchange of opinion. Most correspondence and the intelligence summaries based on it were kept secret. Knowledge of "popular mood" was meant to be a monopoly of Party officials.

In legal cases, the flood of letters to the newspapers was due to the absence of other well-defined channels for appeal. Moreover, the person who wrote a denunciation had only a small chance of securing punishment of its target. Indeed, as Sheila Fitzpatrick suggests, there was a roughly equal chance that the denunciation would rebound against its author. ${ }^{76}$ The chaos in the handling of reader letters and their frequent loss or disappearance into newspaper archives made this channel of appeal even more opaque and its outcomes arbitrary.

Party authorities also solicited letters from worker and village correspondents in order to instruct them in Bolshevik language and ideology. Through written and oral interaction with newspaper editors, "instructors," and Party agitators, activists would master the language of the Soviet state. The Bolshevik leaders conceived of the correspondents movement as a classroom in which rank-and-file members of the Party or the Komsomol would learn Marxism-Leninism. Indeed, not just activists eager to learn official language, but even denouncers attempting to put the state apparatus to their own uses were forced to use official rhetoric and sociopolitical categories to achieve their goals. Those who wished to manipulate the Bolshevik state had to speak its language. Even those with subversive intent ended up propagating official ideology.

As revelations of resistance to the state or the persistence of prerevolutionary worldviews among the Soviet populace, letters to Soviet newspapers are problematic, requiring careful reading and comparison with other sources. But they

75. With the exception of my forthcoming article on "Reader response to the Soviet press campaign against the Trotskii-Zinov'ev opposition," art. cit., which includes a short discussion of the use of letters to the newspapers to prepare reports on popular moods.

76. S. Fitzpatrick, "Signals from below...," art. cit.: 859. 
are a clear window on the functioning of the Bolshevik state and the relationship between Bolshevik officials and their subjects. The letters reveal how Soviet officials shaped the public identity of their subjects through instruction of worker and village correspondents, the establishment of a "hierarchy of consumption," and the use of denunciation as a tool of governance. They are a superb and largely untapped source of information on the everyday practices of state control in the USSR.

Department of History

University of Arkansas/Little Rock

2801 S. University Avenue

Little Rock, AR 72204-1099

e-mail:melenoe@ualr.edu 